\title{
Gastric Ulcer Prevention by Lansoprazole
}

Stalin reddy Challa*, Prasad Garrepally

Department of Pharmaceutics, Jangaon Institute of Parmaceutical Sciences, Jangaon, India

*Corresponding Author : Stalin reddy Challa, Department of Pharmaceutics,Jangaon,India.

Received date: November 26, 2018; Accepted date: December 22,2018;Published date: January 02, 2019.

Citation : Stalin reddy Challa, Prasad Garrepally. Gastric ULCER Prevention by Lansoprazole, J Gastroenterology Pancreatology and Hepatobilary Disorders. 3(1). Doi: 10.31579/2641-5194/007

Copyright : (c) 2019 Stalin reddy Challa. This is an open-access article distributed under the terms of The Creative Commons Attribution License, which permits unrestricted use, distribution, and reproduction in any medium, provided the original author and source are credited.

\begin{abstract}
The objective of the current investigation is to formulate ethyl cellulose and hydroxypropyle methyle cellulose based sustained release microspheres, containing lansoprazole as model drugs. lansoprazole is type II anti-ulcer agent when administered shows synergetic effect in their action. Microspheres were prepared by W/O/O double emulsion solvent evaporation method with different stabilizer concentration and at different speeds of emulsification while maintaining constant amount of lansoprazole. Drug excipient compatibility study was performed prior to formulation development and only compatible excipients were used in the fabrication of microspheres. Prepared microsphere formulations were characterized by percentage yield, particle size analysis, entrapment efficiency, invitro release behavior, differential scanning colorimetry (DSC) and scanning electron microscopy (SEM). SEM studies showed that the microspheres were spherical with rough surface morphology. The drug loaded microspheres showed 10.4-57.9\% entrapment capacity for lansoprazole and The invitro release profile showed a slow and steady release pattern for lansoprazole. A 95-98\% was releases within a period of $12 \mathrm{hrs}$. The drug release was found to be diffusion controlled mechanism. The $\mathrm{n}$ value of Korsmeyer Peppas equation indicated non Fickian type of diffusion.

Keywords: microspheres; lansoprazole; hydroxypropyle methyle cellulose; ethyl cellulose; double emulsion solvent evaporation method; FTIR;SEM; DSC
\end{abstract}

\section{Introduction}

\section{Sustained Release Formulation}

For decades an acute or chronic illness is being clinically treated through delivery of drugs to the patients in form of some pharmaceutical dosage forms like tablets, capsules, liquids, creams, pills, aerosols, injectable, and suppositories with their main discrepancy to maintain drug levels within the therapeutic range. However, these conventional dosage forms have some drawbacks. Multiple daily dosing is inconvenient to the patient and can result in missed doses, made up doses and patient incompliance with the therapeutic regimen. When conventional immediate release dosage forms are taken on schedule and more than once daily, there are sequential therapeutically blood peaks and valley associated with taking each dose. It should be emphasized that the plasma level of a drug should be maintained within the safe margin and effective range.For this, proper and calculated doses of the drug need to be given at different time interval by conventional dosage form. ${ }^{1}$

This is possible through administration of conventional dosage form in a particular dose and particular frequency to provide a prompt release of drug. Therefore to achieve as well as to maintain the concentration within the therapeutically effective range needed by the treatment by repeated administration a day, results in a significant fluctuation in a plasma drug level, leads to several undesirable toxic effects, and poor patient compliance. ${ }^{2}$ The loopholes of the conventional dosage forms lie in their inability:

Controlled drug delivery systems have been introduced to overwhelm the drawback of fluctuating drug levels associated with conventional dosage forms. Various terms like 'smart', intelligent', 'novel', therapeutic have been assigned to controlled release systems.

\section{Methods and Materials}

The following materials of Pharma grade or the best possible Laboratory Reagent grade were used as supplied by the manufacturer.

\begin{tabular}{|c|c|c|c|}
\hline S.No & $\begin{array}{l}\text { CHEMICAL } \\
\text { NAME }\end{array}$ & SOURCE & PURPOSE \\
\hline 1 & Lansoprazole & $\begin{array}{l}\text { MSN Laboratories, } \\
\text { Hyderabad, India }\end{array}$ & Drug \\
\hline 2 & Ethyl Cellulose & $\begin{array}{l}\text { SD Fine chemical Ltd, } \\
\text { Mumbai, India }\end{array}$ & olymer \\
\hline 3 & $\begin{array}{c}\text { Dichloro Methane } \\
\text { (DCM) }\end{array}$ & $\begin{array}{l}\text { SD Fine chemical Ltd, } \\
\text { Mumbai, India }\end{array}$ & Polymer \\
\hline 4 & $\begin{array}{c}\text { Paraffin Liquid } \\
\text { (light) } \\
\end{array}$ & $\begin{array}{c}\text { SD Fine chemical Ltd, } \\
\text { Mumbai, India }\end{array}$ & Solvent \\
\hline 5 & Span 80 & $\begin{array}{l}\text { SD Fine chemical Ltd, } \\
\text { Mumbai, India }\end{array}$ & Stabilizer \\
\hline 6 & N- Hexane & $\begin{array}{l}\text { SD Fine chemical Ltd, } \\
\text { Mumbai, India }\end{array}$ & Solvent \\
\hline 8 & $\begin{array}{l}\text { Potassium } \\
\text { dihydrogen } \\
\text { Phosphate }\end{array}$ & $\begin{array}{l}\text { SD Fine chemical Ltd, } \\
\text { Mumbai, India }\end{array}$ & $\begin{array}{c}\text { Buffer } \\
\text { ingradient }\end{array}$ \\
\hline 9 & NAOH pellets & $\begin{array}{l}\text { SD Fine chemical Ltd, } \\
\text { Mumbai, India }\end{array}$ & $\begin{array}{c}\text { Buffer } \\
\text { ingradient }\end{array}$ \\
\hline
\end{tabular}

Table 1: List of materials used and supplier

\section{Lansoprazole}

Lansoprazole belongs to class of antisecretory compounds, the substituted benzimidazoles that donot exhibit antocholinergic or histamine $\mathrm{H} 2$ receptor antagonist properties but rather supress gastric acid secretion by inhibition of the $\mathrm{H}+\mathrm{K}+$ ions.

Lansoprazole has been charecterised as a gastric acid pump inhibitor in that it blocks the final step of acid production. This effect is dose related and leads to inhibition of both basal and stimulated gastric acid secretion irrespective of the stimulus. Auctores Publishing - Volume 3(1)www.auctoresonline.org Page-01 


\section{Analytical method development}

\section{Preparation of buffer pH 6.8}

$50 \mathrm{ml}$ of the potassium dihydrogen phosphate $(0.2 \mathrm{M})$ was placed in $200 \mathrm{ml}$ volumetric flask and to it $22.4 \mathrm{ml}$ of sodium hydroxide solution $(0.2 \mathrm{M})$ was added and the volume was made upto $200 \mathrm{ml}$ with distilled water.

\section{Preparation of standard solution of lansoprazole:}

Procedure: Accurately weighed $100 \mathrm{mg}$ of lansoprazole drugwas dissolved in $100 \mathrm{~mL}$ of (Conc. $1000 \mu \mathrm{g} / \mathrm{mL}$ ). From this solution, $10 \mathrm{~mL}$ was pipetted out into $100 \mathrm{~mL}$ volumetric flask and volume was made up to with methanol (Conc. $100 \mu \mathrm{g} / \mathrm{mL}$ ). Further $10 \mathrm{ml}$ aliquot was taken from this solution $(100 \mu \mathrm{g} / \mathrm{ml})$ and diluted to $100 \mathrm{ml}$ with methanol to give $10 \mu \mathrm{g} / \mathrm{ml}$ standard solution of drug.

Similarly, standard stock solution was prepared in phosphate buffer $\mathrm{pH}$ 6.8 and methonol.

\section{Preparation of microspheres}

For the preparation of microspheres the double emulsion method was used as suggested by Rama Rao et al. (2005) with slight modifications. The polymer was dissolved in a mixed solvent system (MSS) of acetonitrile and dichloromethane. To this polymer solution glipizide was added and mixed. Then metformin was dissolved separately in 3 $\mathrm{ml}$ of distilled water and added to the polymer solutionwhile stirring to form a primary emulsion. This primary emulsion wasstirred at $450 \mathrm{rpm}$ for 15 min using a mechanical stirrer. Then, this w/o emulsion was poured into liquid paraffin containing Span180 as the surfactant. This was stirred using a mechanical stirrer for $3 \mathrm{~h}$, for the complete evaporation of the solvent. $10 \mathrm{ml}$ of $\mathrm{n}$-hexane was addedas the non solvent after $2 \mathrm{~h}$ of the stirring process. ${ }^{47}$

\section{Treatment and randomization}

All patients who met the inclusion and exclusion criteria received a 1 week course of antihelicobacter therapy containing lansoprazole $30 \mathrm{mg}$, amoxicillin $1 \mathrm{~g}$ and clarithromycin $500 \mathrm{mg}$, given twice daily. This was followed by treatment with lansoprazole $30 \mathrm{mg}$, given daily for 4 weeks. Repeat endoscopy was performed at the end of treatment to check for healing of ulcers and eradication of $\mathrm{H}$. pylori using the methods described above. Patients with unhealed ulcers would be given $30 \mathrm{mg}$ of lansoprazole daily for another 4 weeks. Patients who failed H. pylori eradication, defined as a positive rapid urease test or histology, would receive another 1 week course of triple therapy containing ranitidine bismuth citrate $400 \mathrm{mg}$, amoxicillin $1 \mathrm{~g}$ and metronidazole $400 \mathrm{mg}$, given twice daily. Patients with unhealed ulcers and two unsuccessful eradication treatments of $\mathrm{H}$. pylori were taken out of the study.

\section{Results and Discussion}

In the present investigation an attempt has been made to formulate microspheres of lansoprazole by using biocompatible polymer like ethyl cellulose and hydroxypropyle methyle cellulose as carrier for sustained release. Microspheres were prepared by double emulsion solvent evaporation method. Prepared microspheres are subjected for characterization and evaluation studies.

\section{Characteristics of patients}

Among 102 patients screened during the study period, 45 were suitable for entry into the trial and were given a 1 week course of triple therapy, followed by treatment with lansoprazole. Reasons for exclusion are given in Figure 1. Two patients had persistent $\mathrm{H}$. pylori infection after the first course of eradication therapy; they received the second antihelicobacter therapy and H. pylori was eradicated in both patients. Two patients had persistent ulcers after repeated anti- ulcer treatment and were excluded from the study. The remaining 43 patients were given naproxen $750 \mathrm{mg}$ daily and randomly assigned to receive lansoprazole treatment $(n=22)$ or no treatment $(n=21)$.

\begin{tabular}{|c|c|c|}
\hline & $\begin{array}{l}\text { No treatment group } \\
\quad(n=21)\end{array}$ & $\begin{array}{l}\text { Lansoprazole } \\
\text { group }(n=22)\end{array}$ \\
\hline Mean age, years (range) & $67.1(41-78)$ & $70.2(43-78)$ \\
\hline Age $\geq 65(\%)$ & $13(59.1)$ & $12(57.1)$ \\
\hline Female gender $(\%)$ & $8(36.4)$ & $11(52.4)$ \\
\hline Diagnosis (RA/OA/other) & $6 / 15 / 2001$ & $4 / 17 / 2000$ \\
\hline Smoking (\%) & $3(13.6)$ & $2(9.5)$ \\
\hline Alcohol (\%) & $2(9.1)$ & $2(9.5)$ \\
\hline Co- morbid illnesses $(\%)$ & $8(36.3)$ & $9(42.9)$ \\
\hline $\begin{array}{l}\text { Location of ulcer (gastric } \\
\text { ulcer/duodenal ulcer) }\end{array}$ & $18 / 4$ & $15 / 6$ \\
\hline Ulcer size & $11.2 \pm 4.0$ & $10.3 \pm 4.3$ \\
\hline Bleeding on presentation (\%) & $17(77.3)$ & $13(61.9)$ \\
\hline \multicolumn{3}{|c|}{ Characteristics of ulcer bleeding } \\
\hline $\begin{array}{l}\text { Admission haemoglobin, } \\
\mathrm{g} / \mathrm{dL}\end{array}$ & $9.5 \pm 1.5$ & $9.3 \pm 1.2$ \\
\hline Transfusion required, units & $1.1 \pm 1.3$ & $1.4 \pm 1.2$ \\
\hline Before endoscopy & $0.76 \pm 1.03$ & $1.0 \pm 1.0$ \\
\hline After endoscopy & $0.29 \pm 0.47$ & $0.38 \pm 0.51$ \\
\hline $\begin{array}{l}\text { Median ulcer size, mm } \\
\text { (range) }\end{array}$ & $10.0(5-20)$ & $10.0(5-20)$ \\
\hline $\begin{array}{l}\text { Admission pulse } \geq 100 \\
\text { beats/min }(\%)\end{array}$ & $4(23.5)$ & $3(23.1)$ \\
\hline $\begin{array}{l}\text { Admission systolic BP < } \\
100 \mathrm{mmHg}(\%)\end{array}$ & $4(23.5)$ & $2(15.4)$ \\
\hline Shock at presentation $*(\%)$ & $4(23.5)$ & $2(15.4)$ \\
\hline Serum urea $>10 \mathrm{mmol} / \mathrm{L}$ & $10(58.8)$ & $10(76.9)$ \\
\hline $\begin{array}{l}\text { Location of ulcer (gastric } \\
\text { ulcer/duodenal ulcer) }\end{array}$ & $14 / 3$ & $3-\mathrm{Oct}$ \\
\hline Endoscopic haemostasis (\%) & $7(41.2)$ & $3(23.1)$ \\
\hline
\end{tabular}

Data of standard graph of lansoprazole in ph.6.8 phosphate buffer

\begin{tabular}{|c|c|}
\hline Concentration (ug/ml) & Absorbance in phosphate buffer \\
\hline 10 & 0.083 \\
\hline 20 & 0.162 \\
\hline 30 & 0.243 \\
\hline 40 & 0.325 \\
\hline 50 & 0.398 \\
\hline 60 & 0.482 \\
\hline
\end{tabular}

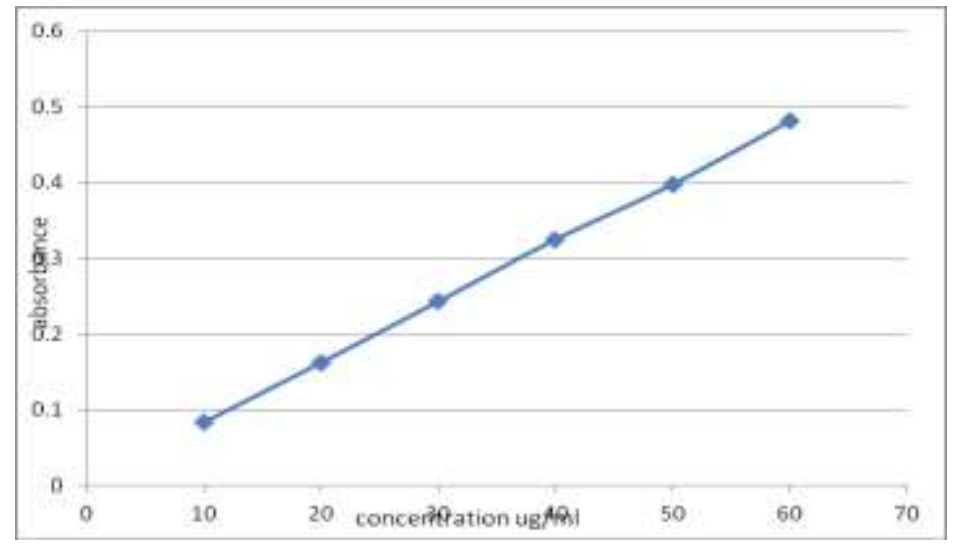

Standard graph of lancoprazole in phosphate Buffer of Ph

\section{Preformulation Studies}

Preformulation study for lansoprazole has been performed to know the drug physical properties so as to design it to a suitable formulation. 


\begin{tabular}{|l|l|}
\hline \multicolumn{1}{|c|}{ Physical property } & lansoprazole \\
\hline Empirical Formula & $\mathrm{C}_{4} \mathrm{H}_{11} \mathrm{~N}_{5} . \mathrm{HCl}$ \\
\hline Molecular Weight & 369.36 daltons \\
\hline Color and odour & White brownish colour powder \\
\hline Taste & Slightly bitter in taste \\
\hline Appearance & Crystalline powder \\
\hline
\end{tabular}

Table: Description data of lansoprazole

Surface Morphology By Sem

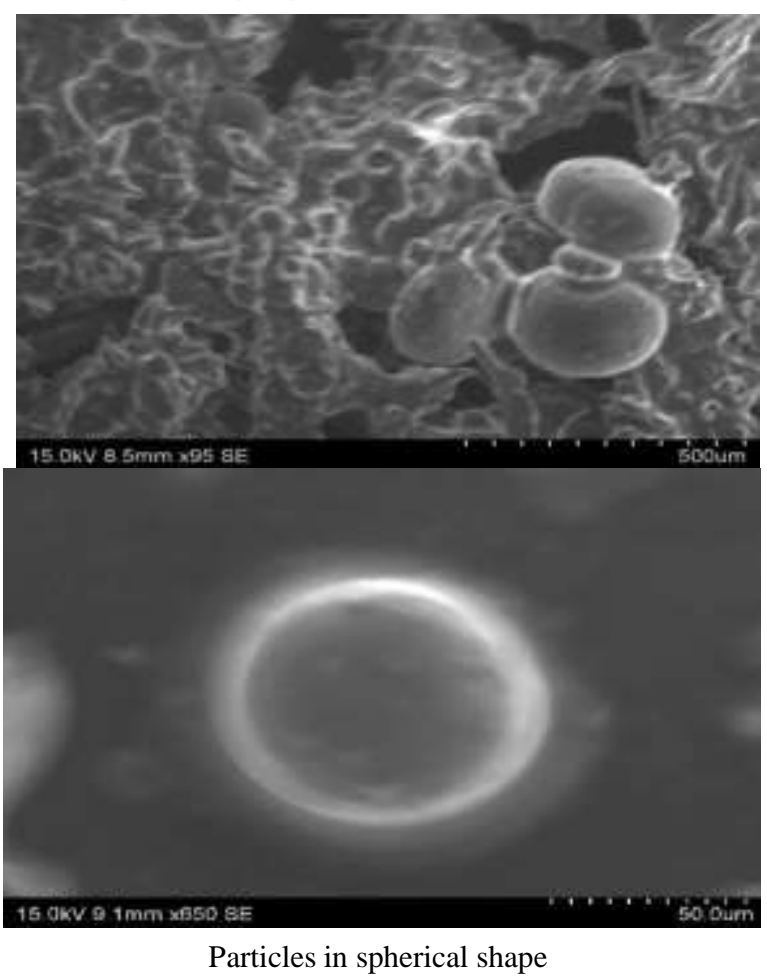

\section{Conclusion}

From the study it is evident that promising sustained release microspheres of lansoprazole may be developed by W/O/O double emulsion solvent diffusion technique by using ethyl cellulose and hydroxyl prople methyle cellulose polymer.

\section{References}

1. Chein YW. Oral drug delivery and delivery system in Novel drug delivery systems. Marcel Dekker, 2nd ed.,New York,1992.

2. Vyas SP. et al., Controlled drug delivery concepts and advances. Vallabh Prakashan, 1st ed., Delhi, 2002.

3. Santo TP. Porus Microspheres for controlled drug delivery. International Journal of Pharmaceutical Research. 1998;10(5):2130 .

4. Gudsoorkar VR. et al., Sustained release of drugs. The Eastern Pharmacist. 1993;36(429):17-22
5. Remington. The science and practice of pharmacy. Lip pin cott Williams and Wilkin s, 21sted, Philadelphia, 2005.

6. Hong WR. et al., Oral controlled formulation design and drug delivery. $1^{\text {st }}$ ed., $1991 ; 136-140$.

7. Jithan A.V. et al., Advances in Drug Delivery. Volume 1, Hyderabad, 2011.

8. Madhu CC. et al., Microspheres as a novel drug delivery system- a review. International Journal of Chemical Technology and Research. 2009; 1(3):526-534.

9. Patel J. Bioadhesion is a topic of current interest in the design of controlled or targeted drug delivery system.

10. Li SP, Kowalski CR, Feld KM, Grim WM. Recent Advances in Microencapsulation Technology and Equipment. Drug Deivery Ind. Pharm. 1988; 14: 353-76.

11. Shanthi NC, Gupta R, Mahato KA, Traditional and Emerging Applications of Microspheres: A Review, International Journal of Pharm. Tech Research. 2010; 2(1):675-81

12. Chandrawanshi P, Patidar H. Magnetic microsphere: As targeted drug delivery. Journal of Pharmacy Res. 2009.

13. Najmuddin M., Ahmed A., Shelar S, Patel V, Khan T. Floating Microspheres Of Ketoprofen: Formulation and Evaluation, International Journal Of Pharmacy and Pharmaceutical sciences. 2010; 2(2):83-87.

14. Yadav AV, Mote HH. Development of Biodegradable Starch Microspheres for Intranasal Delivery, Indian Journal of pharmaceutical Sciences. 2008; 70 (2):170-74.

15. Saralidze K, Leo H., Koole, Menno L, Knetsch W. "Polymeric Microspheres for Medical Applications”, 2010; 3: 3357- 64.

16. Trivedi P, Verma AML, Garud N. Preparation and Characterization of Acclofenac Microspheres, Asian Journal of pharmaceutics, 2008; 2(2): 110-15.

17. Kataria Sahil, Middha Akanksha, Sandhu Premjeet, Ajay Bilandi and Bhawana Kapoor "Microsphere: A Review", International Journal of Research in Pharmacy and Chemistry (IJRPC) 2011, 1(4).

18. Sarlesh rajput, Preeti agrawal, Ashish Pathak, Nikhil Shrivasatava, Satyendra Singh B.,, Rajendra singh B., "A Review on Microspheres: Methods of Preparation and Evaluation", World Journal of Pharmacy and Pharmaceutical Sciences,2012; 1(1):422-438.

19. Alagusundaram.M. et al, "Microspheres as A Novel Drug Delivery System-A Review", International Journal of Chem Tech Research, 2009; 1(3): 526-534.

20. Fischer S., Foreg C., Merkle P.H., Gander B., "Chitosan Coated PLGA-Microspheres-A Modular System for Targetting Drug Delivery", European Cells and Materials, 2004; Vol7:11-1

21. Prashant singh, Prakash D., Ramesh B., Neha singh, Tamizh mani T., "Biodegradable Polymeric Microspheres as Drug Carriers; A Review", Indian Journal of Novel Drug Delivery, 2011; 3(2):70-82.

22. Nithya S. et al., Traditional and emerging application of microspheres: A review. International Journal of Pharmaceutical and Technical Research, 2010; 2(1):675-6 